Pesq. Vet. Bras. 37(2):150-155, fevereiro 2017

DOI: $10.1590 / \mathrm{S} 0100-736 \mathrm{X} 2017000200009$

\title{
Computerized electrocardiogram in agoutis (Dasyprocta prymnolopha Wagler, 1831) anesthetized with ketamine and midazolam ${ }^{1}$
}

\author{
Anaemilia N. Diniz ${ }^{2}$, Gerson T. Pessoa ${ }^{3}$, Laecio da S. Moura ${ }^{4}$, Marina P. Sanches ${ }^{5}$, \\ Renan P.S. Rodrigues ${ }^{5}$, Francisco das C.A. Sousa ${ }^{6}$, Carlos E. Ambrósio ${ }^{7}$ \\ and Flávio R. Alves ${ }^{8 *}$
}

\begin{abstract}
Diniz A.N., Pessoa G.T., Moura L.S., Sanches M.P., Rodrigues R.P.S., Sousa F.C.A., Ambrósio C.E. \& Alves F.R. 2017. Computerized electrocardiogram in agoutis (Dasyprocta prymnolopha Wagler, 1831) anesthetized with ketamine and midazolam. Pesquisa Veterinária Brasileira 37(2):150-155. Departamento de Morfofisiologia Veterinária, Universidade Federal do Piauí, Campus Universitário Ministro Petrônio Portela, Bairro Ininga, Teresina, PI 64049-550, Brazil. E-mail: flavioribeiro@ufpi.edu.br

An electrocardiogram is a test that assesses heart electrical activity and is applied more frequently in the veterinary care of wild animals. The present study aimed to define the electrocardiogram pattern of agoutis (Dasyprocta prymnolopha Wagler, 1831) anesthetized with ketamine and midazolam. Eighteen clinically healthy agoutis (D. prymnolopha) were used from the Nucleus for Wild Animal Studies and Conservation (NEPAS) of the Federal University of Piauí, Brazil. The animals were chemically restrained with 5\% ketamine hydrochloride at a dose of $15 \mathrm{mg} / \mathrm{kg}$ and midazolam at a dose of $1 \mathrm{mg} / \mathrm{kg}$ by intramuscular injection. Electrocardiogram tests were carried out by a computerized method with the veterinary electrocardiogram [Acquisition Model for Computer (ECG - PC version Windows 95) Brazilian Electronic Technology (TEB) consisting of an electronic circuit externally connected to a notebook computer with ECGPC-VET (TEB) software installed on the hard disc. In analysing the EKG results, significant differences were observed for QRS complex duration, PR and QT intervals and for $\mathrm{R}$ wave millivoltage between the genders; but we observed a significant influence of weight despite the gender. In the present experiment, the anaesthetic protocol was shown to be well tolerated by the agoutis, and no arrhythmias occurred during the time the animals were monitored. The reference values obtained should be used to better understand the cardiac electrophysiology of the species and for its clinical and surgical management.
\end{abstract}

INDEX TERMS: Computerized electrocardiogram, agouti, Dasyprocta prymnolopha, ketamine, midazolam, wild animals, rodent, anaesthesia, chemical restraint, cardiology.

\footnotetext{
${ }^{1}$ Received on May 4, 2016.

Accepted for publication on September 4, 2016.

${ }^{2}$ Departamento de Medicina Veterinária, Universidade Federal de Alagoas (UFAL), Rio Largo, Maceió, AL 57100-000, Brasil.

${ }^{3}$ Centro de Ciências Agrárias, Hospital Veterinário Universitário, Universidade Federal do Piauí (UFPI), Teresina, PI 64049-550, Brasil.

${ }^{4}$ Centro de Ciências Agrárias, Pós-Graduação em Ciência Animal, UFPI, Teresina, PI 64049-550, Brasil.

${ }^{5}$ Departamento de Morfofisiologia, Coordenação de Iniciação Científica, UFPI, Teresina, PI 64049-550, Brasil.

${ }^{6}$ Departamento de Medicina, Universidade Estadual do Piauí (UESPI), Teresina, PI 64001-280, Brasil.

${ }^{7}$ Departamento de Medicina Veterinária, Universidade de São Paulo (USP), Av. Duque de Caxias Norte 225, Pirassununga, SP 13635-900, Brasil.

8 Departamento de Morfofisiologia Veterinária, UFPI, Teresina, PI 64049-550, Brasil. *Corresponding author: flavioribeiro@ufpi.edu.br
}

RESUMO.- [Eletrocardiografia computadorizada em cutias (Dasyprocta prymnolopha Wagler, 1831) anestesiadas com cetamina e midazolam.] 0 eletrocardiograma computadorizado é um dos meios de diagnóstico utilizado para avaliação do coração e vem sendo cada vez mais presente na rotina veterinária. Este trabalho teve por objetivo definir o padrão eletrocardiográfico de cutias $(D$. prymnolopha) anestesiadas com cetamina e midazolam. Foram utilizadas 18 cutias clinicamente saudáveis, provenientes do Núcleo de Estudos e Preservação de Animais Silvestres (NEPAS) da Universidade Federal do Piauí. Os animais foram submetidos à contenção química com cloridrato de cetamina a $5 \%$ na dosagem de $15 \mathrm{mg} / \mathrm{kg}$ associado ao midazolam, na dosagem de $1 \mathrm{mg} / \mathrm{kg}$, por via intramus- 
cular. Os exames eletrocardiográficos foram realizados pelo método computadorizado, com o eletrocardiógrafo veterinário (Módulo de Aquisição de ECG Para Computador (ECG - PC versão Windows 95) Tecnologia Eletrônica Brasileira (TEB) composto por um circuito eletrônico ligado externamente a um notebook, e de um software instalado no disco rígido do computador. Os valores de duração do complexo QRS, intervalos PR e QT, comparados entre machos e fêmeas, apresentaram diferença significativa. Em milivoltagem a onda R foi o único parâmetro que apresentou diferença significativa entre machos e fêmeas. 0 peso dos animais também foi significativamente diferente entre os gêneros. 0 protocolo anestésico mostrou-se bem tolerado pelos animais deste experimento, não ocorrendo quadros de arritmias durante o tempo de monitoramento dos animais.

TERMOS DE INDEXAÇÃO: Eletrocardiografia computadorizada, cutia, Dasyprocta prymnolopha, cetamina, midazolam, animais silvestres, roedor, anestesia, contenção química, cardiologia.

\section{INTRODUCTION}

The agouti population has been decreasing to endangered levels, triggering an interest in better understanding its biology and captivity management to preserve the species. (Nogueira-Filho \& Nogueira 2000, Hosken 2001, Alves et al. 2007). In addition, this species is currently used as a biological model in several regions of Brazil (Menezes et al. 2001).

Although there have been previous discussions in the literature, establishing standard clinical criteria for physiologic and organic responses in wild species requires further study (Osofsky et al. 2001, Crissey et al. 2004, Fox et al. 2008, Noszczyk-Nowak et al. 2009). Among these criteria, data about the heart is important for defining homeostatic balance in wild species, but there is little information on this system for this group of animals, with reference values being especially scarce (Heatley 2009, Black et al. 2011, Diniz et al. 2013).

A computerized EKG is a quick, low-cost assessment (Scheer et al. 2010, Gava et al. 2011) of heart electrical activity that has been used in a range of domestic species, such as dogs (Hanton \& Rabemampianina 2006, Neto et al. 2010) and cats (Visser et al. 2014) that has been increasingly proposed for use in the veterinary care of wild and exotic species, such as guinea pigs and ferrets (Dudás-Györki et al. 2011, Morissette et al. 2015). Although in most cases computerized EKG is not part of the routine clinical veterinary care of wild animals, there are reports of conducting this test on various wild species, including ferrets (Mustela putorius furo) (Bublot et al. 2006, Dudás-Györki et al. 2011), species of parrots (Zandiliet 2005) and turtles (Podocnemis expansa) (Carvalho \& Santos 2006).

Most wild species demonstrate unpredictable behaviour during exams, often requiring chemical restraint or general anaesthesia to permit medical, scientific or management procedures. Chemical restraints and general anaesthesia require monitoring physiological parameters such as heart activity, and this emphasizes the need for determining standard EKG values and ideal drugs for this group of animals (Felippe 2007). The use of ketamine and midazolam together for the chemical restraint of wild species promotes adequate myorelaxation and reduces muscular hypertonicity (Valadão 2002). In addition, it promotes tranquillization, hypnosis, amnesia, anti-convulsive activity and can be administered via intramuscular injection with quick absorption and elimination (Paddleford 2001, Massone 2003).

Although useful and safe in most of cases, pharmaceutical drugs used for chemical restraint can lead to cardiovascular alterations, including increased heart frequency, increased blood pressure and myocardial hypoxia (Spinosa et al. 2006). Many of these alterations can be detected by electrocardiogram, and this test is an important tool to detect alterations in the electrocardiographic pattern and diagnose heart disease in animals (Freitas et al. 2009).

As it is known that chemical restraint is necessary for the routine management of wild animals and that these drugs cause alterations in the cardiovascular system, the objective of the present study was to define electrocardiographic standards for agoutis (D. prymnolopha) anesthetized with ketamine and midazolam to provide data to help in monitoring these animals during procedures with this combination of drugs.

\section{MATERIALS AND METHODS}

Animals. Eighteen clinically healthy agoutis (Dasyprocta prymnolopha Wagler, 1831) from the Nucleus for Wild Animal Study and Conservation (Núcleo de Estudos e Preservação de Animais Silvestres - NEPAS) at the Federal University of Piauí, Teresina, Piauí, Brazil, were used. The animals were two-year-old adults weighing between 1.5 and $2.0 \mathrm{~kg}$. They were randomly placed into groups consisting of nine males and nine females. These specimens were first restrained physically to carry out the clinical exam and proof of health. The heart and respiratory frequencies were measured for one minute three times consecutively and defined by the average of the measurements taken. These protocols were approved by the Committee of Ethics in Animal Experimentation (Comitê de Ética em Experimentação Animal (CEEA)) at the Federal University of Piauí (Protocol 0117/2010) and by the Brazilian Institute of the Environment and Renewable Natural Resources (Instituto Brasileiro do Meio Ambiente e dos Recursos Naturais Renováveis (IBAMA)/Biodiversity Authorization and Information System (Sistema de Autorização e Informação de Biodiversidade (SISBIO) (Protocol 26101-1).

Anaesthetic protocol. The animals were chemically restrained with ketamine chloride at $5 \%$ at the dose of $15 \mathrm{mg} / \mathrm{kg}$ in combination with midazolam at the dose of $1 \mathrm{mg} / \mathrm{kg}$ by intramuscular injection. When anaesthetic action was observed, the procedures for the electrocardiogram tests were begun. The protocols gave an average useful anaesthetic time of 40 to 45 minutes in all of the assessments, and therefore there was no need to reapply the drugs during the tests.

Computerized Electrocardiogram (ECG). The electrocardiogram tests were carried out by a computerized method with the veterinary electrocardiogram (ECG Aquision Module for Computer (ECG - PC version Windows 95) Tecnologia Eletrônica Brasileira (TEB) consisting of an electronic circuit linked externally to a notebook computer with software installed on the hard disk. 
After carrying out the test, the results from each animal were analysed, and the waves were measured by the computer.

In all the exams, the tracings were obtained with the animals kept in a right lateral decubitus position on an insulated surface. The tracings started 5 to 10 minutes after administration of the intramuscular injection, shortly after the administered anaesthetic took effect.

The electrodes were specifically distributed over the body of the animal in standardized combinations following the methodology described by Willen Eithoven, and standard electrocardiogram derivations were obtained by the difference in potential among the electrodes.

The right and left thoracic electrodes were placed above the olecranon in its caudal aspect and the right and left pelvic electrodes above the patellar ligaments in the cranial aspect of each limb. The speed used for the recordings was $25 \mathrm{~mm}$ per second, with voltage calibration of $1 \mathrm{~cm}$ for each millivolt $(1 \mathrm{mV}=1 \mathrm{~cm})$.

The aspects assessed were heart rhythm and frequency, duration (milliseconds - ms) and amplitude (millivolts - $\mathrm{mV}$ ) of the P wave, PR interval and QRS complex; R wave amplitude, levelling of the ST segment, QT interval (milliseconds - ms) and the T wave polarity. These were all analysed in bipolar II derivations (DII) and the electrocardiogram measurements were analysed according to Tilley (1992). No animals presented any significant electrocardiogram alterations that could arouse suspicion of heart disease.

Statistical analysis. The data were submitted to the normality test (Shapiro-Wilk and Kolmogorov-Smirnov) and later the means of the male and female groups were analysed by the Student test (T-test) for the $5 \%$ interval $(\mathrm{p}<0.05)$.

\section{RESULTS}

The animals used in the experiment presented mean weight values of $2.46 \pm 0.20 \mathrm{~kg}$ for the males and $2.30 \pm 0.17 \mathrm{~kg}$ for the females. The mean heart frequency ranged from 142 to $149 \mathrm{bpm}$, and the highest frequencies were found in male individuals, but there was no significant difference between males and females.

The values found for the parameters assessed in the electrocardiogram are shown in Table 1 (P wave duration and amplitude, QRS complex duration, QT interval and PR duration and $\mathrm{R}$ wave and T wave amplitude) (Fig.1).

The $\mathrm{P}$ wave duration found for the males was $9.45 \pm 8.3$ (ms) and $40.54 \pm 6.89(\mathrm{~ms})$ for the females, but there was no significant difference between the values obtained. The $\mathrm{P}$ wave amplitude showed a significant difference, and values of $0.096 \pm 0.033 \mathrm{mV}$ were found for the males and $0.11 \pm 0.03 \mathrm{mV}$ for the females. There was also a significant difference between males and females for the values and duration in milliseconds of the QRS complex (females $58.28 \pm 17.72$ and males $47.31 \pm 7.65$ ), PR interval duration in milliseconds (females 85.91 \pm 21.68 and males 77.73 \pm 13.07 ) and QT interval duration (females $231.82 \pm 33.81$ and males $220.37 \pm 20.66$ ). It is important to note that in the three last parameters mentioned, the values found for the females were always greater than those found for the males.

The R amplitude was significantly different between the genders, with the values in millivolts of $0.40 \pm 0.22 \mathrm{mV}$ for the males and $0.53 \pm 0.32 \mathrm{mV}$ for the females. The $\mathrm{T}$ wave amplitude was also shown to be different among the male and female individuals, but there was no statistical significance, though the amplitude was greater for the males $(0.21 \pm 0.087 \mathrm{mV})$ than for the females $(0.19 \pm 0.095 \mathrm{mV})$. Regarding the $\mathrm{T}$ wave polarity, there were fewer differences among the female individuals that presented positive wave polarity in $92.98 \%$ and negative polarity in $7.02 \%$ of the animals examined, while individuals of the male sex had a more marked difference, with $57.15 \%$ of the individuals presenting positive wave polarity and $42.85 \%$ presenting negative wave polarity (Fig.1).

The heart rhythm was predominantly sinus, presenting in $100 \%$ of the animals assessed. The heart axis ranged from $-160^{\circ}$ to $180^{\circ}$, with no difference between the males and females.

\section{DISCUSSION}

In agouti, as in other wild animals, sedation is necessary in veterinary care but causes alterations in the functioning of the cardio vascular system (Hamlin 2006). As a result, it is important to know the standard electrocardiogram pattern so that individuals can be monitored throughout a procedure (Diniz et al. 2013).

The heart frequency values found for agouti anesthetized with ketamine and midazolam were higher than for wild species such as leopards and cheetahs, but the results were similar to those for wolves, dogs and cats (Martin 2002, Tilley \& Goodwin 2002). They were lower than the values found for rats and ferrets (Lord et al. 2010). Taking into consideration that the smaller the animal, the higher its heart frequency, we could state that the heart frequency of the agouti in the present study was lower than in animal species of the same size when not anesthetized. Thus, similar to observations in non-anesthetized agoutis (Diniz et al. 2013), male individuals presented a higher heart frequency, but there was no significant difference between males and females.

The animals in the present research had a lower mean heart frequency than non-anesthetized agouti (Diniz et al. 2013) and other similarly sized species, such as rabbits (Lord et al. 2010) and ferrets (Wagner 2009). The decreased heart frequency in the present study can be attributed to the bradycardiac action of xylazine (Thurmon et al. 1999). There were no previous electrocardiogram parame-

Table 1. Duration and amplitude of the $P$ wave, $Q R S$ complex duration, $Q T$ interval and PR and amplitude of the $R$ wave of the agouti (Dasyprocta prymnolopha Wagler, 1831), Teresina, Piauí, Brazil

\begin{tabular}{|c|c|c|c|c|c|c|c|}
\hline & $\mathrm{P}(\mathrm{ms})$ & QRS (ms) & PR (ms) & QT (ms) & $\mathrm{P}(\mathrm{mV})$ & $\mathrm{R}(\mathrm{mV})$ & $\mathrm{T}(\mathrm{mV})$ \\
\hline Male & $39.45 \pm 8.31$ & $47.31 \pm 7.65^{\mathrm{a}}$ & $77.73 \pm 13.07^{a}$ & $220.37 \pm 20.66^{a}$ & $0.096 \pm 0.033^{\mathrm{a}}$ & $0.40 \pm 0.22^{\mathrm{a}}$ & $0.21 \pm 0.09$ \\
\hline Female & $40.54 \pm 6.89$ & $58.28 \pm 17.72^{\mathrm{b}}$ & $85.91 \pm 21.68^{\mathrm{b}}$ & $231.82 \pm 33.81^{\mathrm{b}}$ & $0.11 \pm 0.03^{\mathrm{b}}$ & $0.53 \pm 0.32^{\mathrm{b}}$ & $0.19 \pm 0.09$ \\
\hline T-test & $\mathrm{p}=0.46 ; \mathrm{p}>0.05$ & $\mathrm{p}=0.000061 ; \mathrm{p}<0.05$ & $\mathrm{p}=0.019 ; \mathrm{p}<0.05$ & $\mathrm{p}=0.035 ; \mathrm{p}<0.05$ & $\mathrm{p}=0.013 ; \mathrm{p}<0.05$ & $\mathrm{p}=0.012 ; \mathrm{p}<0.05$ & $\mathrm{p}=0.2 ; \mathrm{p}>0.05$ \\
\hline
\end{tabular}

* Different letters indicate significant differences in the same column. 


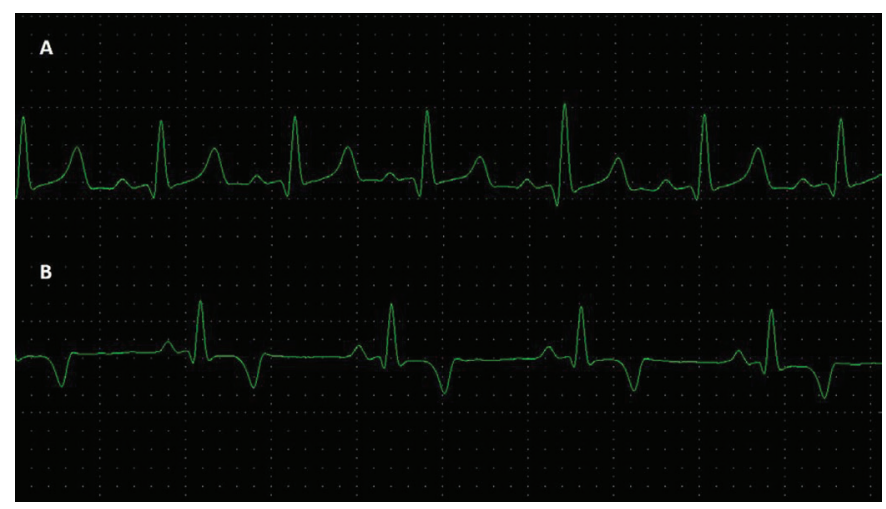

Fig.1. Electrocardiographic tracing of agouti (Dasyprocta prymnolopha Wagler, 1831), Teresina, Piauí, Brazil. (A) QRS pattern observed in $92.98 \%$ females (positive wave polarity). (B) Standard QRS observed in $42.85 \%$ males (negative wave polarity).

ters for agoutis anesthetized with ketamine and midazolam; therefore, the reactions that occurred in the present experiment were assessed according to the expected effect of the drug and anaesthetic on other species.

The tracing morphology and values found in the present experiment were similar to those reported for animals of the same species given an electrocardiogram without chemical restraint (Diniz et al. 2013). Furthermore, the electrocardiogram morphology of these wild rodents was similar to that reported for domestic species such as dogs (Tilley 1992) and rabbits (Reusch 2005, Lord et al. 2010).

The duration of the P wave in the animals studied was longer than the values presented for individuals of the same species without anaesthesia. The P wave amplitude in the sedated animals was significantly different for males and females and was higher in the females. There are no reports of this difference between the genders in non-anesthetized agoutis (Diniz et al. 2013). In other studies, the difference in $\mathrm{P}$ wave amplitude was associated with the change of decubitus needed to carry out the examination in ferrets (Bublot et al. 2006). In the present study however, the positioning of the animals was the same for all the individuals, suggesting differences in the $\mathrm{P}$ wave amplitude. In rabbits that were given an electrocardiogram, the $\mathrm{P}$ wave showed different morphology in some breeds, but without any pathological significance (Reusch 2005).

The PR interval found in the agouti was inversely related to heart frequency when the values for the males and females were compared. Thus, the males that presented higher heart frequency had lower PR values than the females. The inverse proportion of these values is reported in humans in normal physiological condition. Non-anesthetized agouti presented similar values for this characteristic, and the relationship with heart frequency was also observed to be higher for the males, as in the present experiment (Diniz et al. 2013).

The QT interval was greater for female non-anesthetized agouti (Diniz et al. 2013), similar to the present experiment, but the duration of this interval in the agoutis anesthetized with ketamine and midazolam was greater than that found in physically restrained agouti. Booth (1992) showed that in a perfused isolated rat heart, ketamine altered electric activity, prolonging the QRS and QT intervals, which likely negatively interfered with the myocardial repolarization of the animals in the present experiment. Eckardt et al. (1998) associated an increase in QT interval duration to an occurrence of arrhythmias, and a study with rabbits reported that the females presenting a greater QT interval were the most susceptible to induced arrhythmias (Lu et al. 2001).

These two reasons reported in other species suggest the cause of the variability in the duration of the QRS complex. In rabbits, this variability would be due to the flexibility of their skin (Slapak \& Hermanek 1957, Saitanov 1960, Szabuniewicz \& Szabuniewicz 1978), and in sloths it is due to the presence of their gastric contents (Silva et al. 2005). In the present study, there was no interference from either of these factors because agouti skin is not very flexible and the gastric contents were removed by fasting before the experiment, a necessary procedure for the administration of anaesthesia. Thus, the values found for QRS in agouti anesthetized with ketamine and midazolam were similar to those found for the same species without anaesthesia, and in both experiments, the difference between males and females was significant, and the values for the females were higher.

One of the parameters adopted to assess ventricular repolarization is the duration of the QT interval (Eckardt et al. 1998). In the present experiment, the females had a greater QT interval than the males, thus indicating the need for a longer time for repolarization in this gender. In nonanesthetized agoutis, the same characteristic was presented, which indicates little or no interference from the anaesthetics used in the present study on heart repolarization. A study with rabbits showed that the females had a greater tendency to present heart arrhythmias due to a higher QT interval (Lu et al. 2001), but the animals in the present experiment were assessed, and any individual presenting indications of heart disease was eliminated from the study.

In a study with non-anesthetized agouti, $\mathrm{T}$ wave amplitude values were greater in the males than in the females (Diniz et al. 2013). These results were also observed in the present experiment, but there was no significant difference. In addition, the male $\mathrm{T}$ wave corresponded to approximately $50 \%$ of the anterior R wave, while for the females, the $\mathrm{T}$ wave corresponded to approximately $35 \%$ of the anterior $\mathrm{R}$ wave. When compared with non-anesthetized agouti, the T wave of the males reached almost $100 \%$ of the size of the anterior $\mathrm{R}$ wave, and in the females, this value was $70 \%$. This relationship was studied in dogs and cats and it was found that the T wave can measure up to $25 \%$ of the R wave (Tilley 1992), and above this percentage, the $\mathrm{T}$ wave indicates a process of myocardial hypoxia in the species. In humans, it is considered that high amplitudes of the $\mathrm{T}$ wave can occur in $2.5 \%$ to $14 \%$ of adult individuals, without evidence of heart disease or cardiac extra (Lazzoli et al. 2002). However, it is one of the parameters taken into consideration when myocardial infarction is suspected.

The assessment of heart muscle lesions caused by oxygen reduction requires more detailed imaging studies. Ho- 
wever, we can conclude from the present study that the agoutis sedated with ketamine and midazolam tolerated this combination and the oxygen supply to the myocardium was reduced, because the anaesthetic recovery was $100 \%$ in the animals, with no report of complications. Furthermore, it can be suggested that the chemical restraint process generates fewer alterations in heart oxygenation than physical restraint because there were fewer discrepancies in $\mathrm{T}$ wave values than $R$ wave values.

The $\mathrm{T}$ wave morphology was varied, including the aspect of being positive or negative, but this characteristic is observed in other species; therefore, it is suggested that previous electrocardiograms of the same animal should be assessed (Hamlin et al. 1986).

In rodents, the relation of heart size to thorax size is extremely varied. The variation in this relationship can lead to alterations in the position of the heart inside the thorax and consequently to changes in the electrical axis of the heart. This electrocardiogram parameter is used to assess alterations in the ventricle size (Hamlin et al. 1986). The animals studied had the same electrical axis measurement as that presented by non-anesthetized agouti $\left(-160\right.$ to $\left.180^{\circ}\right)$ (Diniz et al. 2013), and there was little variation in the syntopic relationship between the heart and the thoracic cavity, reaffirming the morphological aspect of the thoracic cavity of this species. The values of the electric axis for agoutis are closer to those found for rabbits (Reusch 2005, Lord et al. 2010) than those reported for cats (Tilley 1992), even though the latter species is similar in size to the animals studied. As a result, we can understand that the relation of the heart size to the thorax directly influences the heart axis of each species (and even each breed within the same species, as reported for dogs by Tilley (1992)); therefore, specific studies are needed to determine the standard for each species.

\section{CONCLUSIONS}

The electrocardiogram test of the agouti anesthetized by the combination of ketamine and midazolam allowed for the acquisition of diagnostic quality ECG tracing.

The tracing pattern and measurements obtained in the present experiment suggest that the anaesthetic protocol used was well tolerated by the agouti studied.

There were discrete conformation alterations in the tracings and measurements (without statistical significance), and there were no complications, such as ectopic rhythms, which are common in the clinical surgical management of this species.

Therefore, this protocol was used as a routine assessment in the rearing centres of wild and zoological animals, demonstrating its efficacy as a sedative/anaesthetic and as a method for reducing the need for chemical restraint of this species during procedures (and thus the risk of death associated with this practice).

Acknowledgements.- The authors thank the Diagnosis by Image Sector of the University Veterinary Hospital, UFPI, the UFPI Nucleus for Wild Animal Research and Preservation for making the animals available and CAPES for the doctorate grant.

\section{REFERENCES}

Alves F.R., Costa F.B., Arouche M.M.S., Barros A.C.E., Miglino M.A., Vulcano L.C. \& Guerra P.C. 2007. Avaliação ultra-sonográfica do sistema urinário, fígado e útero do macaco-prego, Cebus apella. Pesq. Vet. Bras. 27:377382.

Black P.A., Marshall C., Seyfried A.W. \& Bartin A.M. 2011. Cardiac assessment of African hedgehogs (Atelerix albiventris). J. Zoo Wildl. Med. 42:49-53.

Booth N.H. 1992. Anestésicos intravenosos e outros parenterais, p.168218. In: Booth N.H. \& McDonald L.E. (Eds), Farmacologia e Terapêutica em Veterinária. 6th ed. Guanabara Koogan, Rio de Janeiro.

Bublot I., Randolp R.W., Chalvet-Monfra K. \& Edwards N.J. 2006. The surface electrocardiogram in domestic ferrets. J. Vet. Cardiol. 8:87-93.

Carvalho S.F.M. \& Santos A.L.Q. 2006. Valores das ondas do eletrocardiograma de tartarugas-da-Amazônia (Podocnemis expansa Schweigger, 1812) (testudines). Ars Vet. 22:117-121.

Crissey S.D., Ange K.D., Slifka K.A., Kahn S.W.S. \& Ward A.M. 2004. Serum lipid concentrations in six canid and four ursid species in four zoos. J. Zoo. Wildl. Med. 35:34-39.

Diniz A.N., Silva-Junior J.R., Ambrosio C.E., Sousa J.M., Sousa V.R., Carvalho M.A.M., Nascimento D.N. \& Alves F.R. 2013. Thoracic and heart biometrics of non-anesthetized agouti (Dasyprocta primnolopha Wagler, 1831) measured on radiographic images. Pesq. Vet. Bras. 33:411-416.

Dudás-Györki Z., Szabó Z., Manczur F. \& Vörös K. 2011. Echocardiographic and electrocardiographic examination of clinically healthy, conscious ferrets. J. Small Anim. Pract. 52:18-25.

Eckardt L., Haverkamp W., Borggrefe M. \& Breithardt G. 1998. Experimental models of torsade de pointes. Cardiovasc. Res. 39:178-193.

Felippe P.A.N. 2007. Eletrocardiografia, p.920-929. In: Cubas Z.S., Silva J.C.R. \& Catão-Dias J.L. (Eds), Tratado de Animais Selvagens: medicina veterinária. Roca, São Paulo.

Fox M., Brieva C., Moreno C., MacWilliams P. \& Thomas C. 2008. Hematologic and serum biochemistry reference values in wild-caught white-footed tamarins (Saguinus leucopus) housed in captivity. J. Zoo Wildl. Med. 39:548-557.

Freitas M.V., Ferreira F.S., Silveira L.L., Soares S. \& Carvalho C.B. 2009. Análise comparativa de eletrocardiogramas de cães em 1 e 2 Mv. J. Bras. Ciênc. Anim. 2:159-165.

Gava F.N., Paulino-Junior D., Pereira-Neto G.B., Pascon J.P.E., Sousa M.G., Champion T. \& Camacho A.A. 2011. Computerised electrocardiograph in Beagle dogs. Arq. Bras. Med. Vet. Zootec. 63:317-321.

Hamlin R.L., Hren J. \& Sparrow P.V. 1986. Electrocardiographic evaluation of the healthy raccoon, Procyon lotor. Am. J. Vet. Res. 47:814-817.

Hamlin R.L. 2006. Fisiologia cardiovascular, p.17-18. In: Abbott J.A. (Ed.), Segredos em Cardiologia de Pequenos Animais. Artmed, Porto Alegre.

Hanton G. \& Rabemampianina Y. 2006. The electrocardiogram of the Beagle dog: reference values and effect of sex, genetic strain, body position and heart rate. Lab. Anim. 40:123-36.

Heatley J.J. 2009. Cardiovascular anatomy, physiology, and disease of rodents and small exotic mammals. Vet. Clin. Exot. Anim. 12:99-113.

Hosken F.M. 2001. Manejo de cutias, p.21-22. In: Hosken F.M. \& Silveira A.C. (Eds), Criação de Cutias. Aprenda Fácil, Viçosa, MG.

Lazzoli J.K., Castro C.L.B., Nóbrega A.C.L. \& Araújo C.G.S.A. 2002. Acurácia de critérios para vagotonia no eletrocardiograma de repouso de 12 derivações: uma análise com curvas ROC. Revta Bras. Med. Esp. 8:50-58.

Lord B., Boswood A. \& Petrie A. 2010. Electrocardiography of the normal domestic pet rabbit. Vet. Rec. 167:961-965.

Lu H.R., Remeysen P., Somers K., Saels A. \& De Clerck F. 2001. Female gender is a risk factor for drug-induced 1long QT and cardiac arrhythmias in an in vivo rabbit model. J. Cardiovasc. Electrophysiol. 12:538-545.

Martin M. 2002. ECG interpretation in small animals: practical guidelines. In Practice 24:250-261.

Massone F. 2003. Anestesiologia Veterinária: farmacologia e técnicas. Guanabara Koogan, Rio de Janeiro, p.233-234. 
Menezes D.J.A., Carvalho M.A.M., Cavalcante Filho M.F. \& Souza W.M. 2001. Configuration of the portal venous system in agoutis (Dasyprocta aguti, Rodentia). Braz. J. Vet. Res. Anim. Sci. 38:263-266.

Morissette P., Regan H.K., Fitzgerald K., Bernasconi S., Gerenser P., Travis J., Fanelli P., Sannajust F. \& Regan C.P. 2015. QT interval correction assessment in the anesthetized guinea pig. J. Pharmacol. Toxicol. Methods 75:52-61.

Nogueira-Filho S.L.G. \& Nogueira S.S.C. 2000. Criação comercial de animais silvestres: produção e comercialização da carne e de subprodutos na região sudeste do Brasil. Revta Econom. Nord. 31:188-195.

Noszczyk-Nowak A., Nicpoń J., Nowak M. \& Slawuta P. 2009. Preliminary reference values for electrocardiography, echocardiography and myocardial morphometry in the European brown hare (Lepus europaeus). Acta Vet. Scand. 51:1-6.

Osofsky A., Jowett P.L.H., Hosgood G. \& Tully T.N. 2001. Determination of Normal Blood Concentrations of Lead, Zinc, Copper, and Iron in Hispaniolan Amazon Parrots (Amazona ventralis). J. Avian Med. Surg. 15:31-36.

Paddleford R.R. 2001. Manual de Anestesia em Pequenos Animais. Roca, São Paulo. 22p.

Pereira Neto G.B., Brunetto M.A., Sousa M.G., Carciofi A.C. \& Camacho A.A. 2010. Effects of weight loss on the cardiac parameters of obese dogs. Pesq. Vet. Bras. 30:167-171.

Reusch B. 2005. Investigation and management of cardiovascular disease in rabbits. In Practice 27:418-425.

Saitanov A.0. 1960. Standard and thoracic lead electrocardiography in normal rabbits and methods for its registration. Biulleten Eksperimental'noi Biologii I Meditsiny 49:102-109.

Scheer P., Svoboda P., Sepsi M., Janecková K. \& Doubek J. 2010. The electro- cardiographic Holter monitoring in experimental veterinary practice. Physiol. Res. 1:59-64.

Silva E.M., Duarte D.P.F. \& Costa C.P. 2005. Electrocardiographic studies of the three-toed sloth, Bradypus variegatus. Braz. J. Med. Biol. Res. 38: 1885-1888.

Slapak L. \& Hermanek P. 1957. Observations on the electrocardiogram of rabbits. Zeitschrift für Kreislaufforschung 46:136-142.

Spinosa H.S., Górniak S.L. \& Bernardi M.M. 2006. Farmacologia Aplicada à Medicina Veterinária. Guanabara Koogan, Rio de Janeiro, p.353-355.

Szabuniewicz J.M. \& Szabuniewicz M. 1978. The electrocardiogram of the Virginia opossum Didelphis virginiana. Zentralbl. Veterinärmed. 25:785793.

Thurmon J.C., Tranquilli W.J. \& Benson C.J. 1999. Essentials of Small Animal Anesthesia and Analgesia. Lippincott Williams and Wilkins, Philadelphia. 580p.

Tilley L.P. 1992. Tables for determining the frontal plane mean electrical axis, p.443-447. In: Tilley L.P. (Ed.), Essentials of Canine and Feline Electrocardiography. 3rd ed. Lippincott Williams and Williams, Philadelphia.

Tilley L.P. \& Goodwin J.K. 2002. Manual de Cardiologia para Cães e Gatos. $3^{\underline{a}}$ ed. Roca, São Paulo. 489p.

Valadão C.A.A. 2002. Anestésicos dissociativos, p.165-173. In: Fantoni D.T. \& Cortopassi S.R.G. (Eds), Anestesia em Cães e Gatos. Roca, São Paulo.

Visser L.C., Scansen B.A. \& Bonagura J.D. 2014. ECG of the Month: escape-capture bigeminy in a cat. J. Am. Vet. Med. Assoc. 245:52-54.

Wagner R.A. 2009. Ferret cardiology. Vet. Clin. North Am., Exotic Anim. Pract. 12:115-134.

Zandiliet M.J.M. 2005. Electrocardiography in psittacine birds and ferrets. Semin. Avian Exotic Pet Med. 14:34-51. 